Managing ensemble scale heritage conservation in the Shandon Architectural

Conservation Area in Cork, Ireland

Tony Matthews *

School of Environment,

Griffith University,

170 Kessels Road,

Nathan, Queensland 4001,

Australia.

* Corresponding Author - email: t.matthews@griffith.edu.au

\title{
Deanna Grant-Smith
}

School of Management,

QUT Business School,

Queensland University of Technology,

2 George Street,

GPO Box 2434,

Brisbane, Queensland 4001,

Australia.

\section{Full citation:}

Matthews, T. and Grant-Smith, D. (2017) 'Managing ensemble scale heritage conservation in the Shandon Architectural Conservation Area in Cork, Ireland.' Cities. 62: 152-158.

doi:10.1016/j.cities.2016.10.004 


\section{Introduction}

Functioning as an intergenerational repository of cultural meaning, built heritage artefacts form an important part of the cultural history of settlements (Al-hagla 2010; Tweed and Sutherland 2007) and act as 'dispensers of cultural identity' (Bianca 2010, 28) for modern urban areas around them by providing a tangible connection to the past. Conserving built heritage can thus promote intergenerational equity by preserving cultural capital for the benefit of future generations (Taylor 2013). However, just as historic urban areas shape society, they are also subject to change and reshaping to satisfy society's evolving needs and values (Nepravishta 2015). Although urban ensembles now constitute the largest category within the UNESCO World Heritage List (UNESCO 2011), the conservation of urban heritage has been recognised as a 'daunting task' (van Oers 2010, 7).

The conservation of urban ensembles extends beyond the consideration of individual buildings and structures and instead focuses on clusters of buildings, streets or entire districts. An urban heritage ensemble is characterized by 'an overall architectural quality or historical association...often denoting a significant historical and social relationship to the rest of the town' (Nasser 2003, 469). The conservation of ensembles is a critical component of urban planning as rapid urbanisation and other pressures may threaten cultural histories (Whitehand and Gu 2010; Pendlebury, Short and While 2009). The conferral of conservation status on specific ensembles is a response to this (Harvey 2001; Whitehand and Gu 2010).

Conservation planning is concerned with safeguarding the material heritage of both individual buildings and ensembles (Pendlebury 2013). Applying conservation status to an ensemble can preserve its cultural and architectural heritage, help define its character, enhance the overall built environment, and contribute to social and community wellbeing (Tweed and Sutherland 2007; Skea 1996). It has also been suggested that it can impact residential property values and local economic development (e.g. see Ashworth 2002; 
Shipley 2000). However, it is imperative that that ensemles not be identified and managed 'as separate entities within a larger whole' (van Oers 2010,12). Instead they must be managed through an integrated, planning-led approach that considers interrelated physical, spatial, social and political dimensions (Orbasli 2000, 2008).

Much of the extant literature regarding residential areas that include heritage ensembles has focussed on the economic impacts of heritage designation, particularly in a North American context. The contribution of this paper is its exploration of the nature and character of formalised processes of built heritage conservation in an Irish urban area that has been continuously inhabited for over 800 years. The extent to which objectives of complementarity, compatibility, continuity and connection can be achieved through conservation efforts targeted at the ensemble scale in this context are critically explored through a case study of the statutorily defined Architectural Conservation Area of Shandon in the City of Cork, Ireland.

\section{The evolution of heritage conservation through urban planning}

Interest in built heritage conservation in the UK and Ireland can be traced to the eighteenth century when young, upper-class British men began the tradition of 'grand tours' to Europe (Skea 1996). As a result of exposure to art and architecture during these expeditions, the British ruling classes supported the conservation and restoration of certain landmark architecture in Great Britain such as grand residences, churches and cathedrals. This focus on restoring specific edifices persisted until the 1960s, when interest widened to include the conservation of heritage ensembles (Nasser 2003). The emergent appreciation of the value of ensemble conservation was linked to a growing understanding that 'to isolate a building...ruptures continuity with its cultural and historical context, thereby preventing people from interpreting it richly and usefully' (Handler 1987, 138). 
Heritage ensembles deemed worthy of conservation are identified using a combination of aesthetic, economic and historic values (Cho and Shin 2014). Conservation decisions are thus shaped by deliberative and value-led appraisals which determine what and whose heritage is worth preserving (Maginn 2014; Veldpaus, Pereira Roders and Colenbrander 2013). Certainly locally focused appraisal allows the special characteristics of an area to be more fully appreciated through processes of community engagement that recognise and mobilise the innate knowledge communities of their local area (Skea 1996). The local determination of heritage ensembles can also ensure that conservation becomes a fundamental part of local planning activity, whilst actively engaging communities in decision making processes that have spatial and material impacts upon them and their locale (Cho and Shin 2014). However, it must be recognised that such an endeavour is not apolitical. Heritage ensembles are generally popular with residents and business owners who tend to be supportive of local conservation efforts. The perception of certainty linked to the past, expressed through built heritage, is a powerful factor in mobilising public support for conservation ensembles, perhaps due to an nostalgia and an intrinsic feeling that historic townscapes buffer individuals against upheaval and stress associated with uncertainties about the future (Harrison 2013; Hubbard 1993; Johnson 1996).

Urban planning can play an important role in identifying, regulating, managing and conserving built heritage through specific conservation planning processes (Nasser 2003; Pendlebury 2013; Whitehand and Gu 2010). Effective conservation planning requires that changes to structures and spaces be carefully managed to ensure the long-term survival of heritage ensembles within broader urban spaces (Harvey 2001; Nasser 2003; Ryberg-Webster and Kinahan 2014). Successfully designating and managing ensembles with strong heritage value requires planning processes to maintain a careful balance between economic development and the care of fragile historic fabric (Pickard 2002; Townshend and Pendlebury 
1999). Designating an ensemble a conservation area can help by providing layers of legal and administrative protection designed to safeguard an area's distinct built heritage (Skea 1996; Tweed and Sutherland 2007). Such protections can ensure that heritage ensembles will generally be spared from the cycle of demolition and rebuilding that characterises much urban (re)development. They can also be subject to more targeted development management regulations and planning strategies designed to preserve their unique form, appearance and character.

\section{Ensemble-scale heritage conservation through urban planning in Ireland}

Ensemble-scale conservation has been recognised in European countries as an important planning tool to protect areas of distinctive heritage value. Preserving built heritage is a key task of urban planning in Ireland (DAHG 2011; Negussie 2004). The Irish planning system protects built heritage, including ensembles, through the use of legal and regulatory criteria (Pickard 2002). Ireland's basis for national commitment to heritage conservation derives from its ratification of the Council of Europe's Convention for the Protection of Architectural Heritage of Europe. The current national planning legislation in Ireland is the Local Government (Planning and Development) Act 2000.

Ireland's planning system derives from national scale legislation but is operated on the local scale by local planning authorities. Each planning authority is responsible for ensuring that planning and development processes, heritage conservation activities and policies provided within local development plans are compatible with the national legislation and associated statutory regulation (Bannon and Bradley 2007). Irish planning law nominates An Taisce, the National Trust for Ireland, as a prescribed body. This means that An Taisce may be consulted by local planning authorities on planning issues relating to heritage and may also autonomously offer opinion on heritage issues through public consultation 
processes. Whilst the devolution of conservation practice to local authorities from central government is standard in Ireland, the approach has provoked some criticism. This principally relates to the propensity of the arrangement to undermine overall conservation efforts due to a lack of uniform approaches and standards across local jurisdictions (Hobson 2001).

A conservation ensemble is known as an Architectural Conservation Area (ACA) under Irish planning provisions. Some high-profile ACAs in Ireland include: Grafton Street, Fitzwilliam Square, and O'Connell Street in Dublin; Kilkenny Castle and the medieval core of Kilkenny town; the city core in Galway; and Adare Manor and environs in County Limerick. However, while the title of architectural conservation area may nominally suggest that an ACA exists principally for the purposes of architectural conservation, the ACA mandate is far broader. An ACA is legally recognised as 'a place, area, group of structures or townscape which is either of special architectural, historical, archaeological, artistic, cultural, scientific, social or technical interest in its own rights or which contributes to the appreciation of protected structures' (DAHG 2011, 41). As such, the scope of an ACA extends beyond architectural heritage to incorporate a much wider set of built environment features.

Conferral of ACA status on ensembles in Ireland is achieved through their inclusion in a local planning authority's main development plan (DAHG 2011). Conservation practices in Ireland are framed by professional discourses but also intersect with wider societal values (Parkinson, Scott and Redmond 2016). Consequently, community and stakeholder consultation is a key feature of the designation process to ensure that the views of the public are represented and inform decisions relating to the identification and designation of ACAs. Designation of an ensemble as an ACA provides statutory planning and heritage protection of existing heritage building stock and features through sensitive maintenance (for example, see CCC 2009b). It also provides for the enforcement of strict design and materials standards for 
new developments. Applications for development consent in ACAs are considered first by the relevant local planning authority but there are provisions for An Taisce to be notified. An Taisce are entitled, though not required, to provide comment on development proposals in ACAs. Disputed decisions may be referred to An Bord Pleanála, Ireland's statutory planning appeals body. The roll-out of ACAs across Ireland been somewhat inconsistent since their inclusion in the Local Government (Planning and Development) Act 2000. At last count Cork city contained sixteen ensemble-scale ACAs and twenty smaller ACAs largely comprising groups of terraced houses (CCC 2014). By contrast, Dublin, a much larger city, hosts only fourteen ACAs (Dublin City Council 2016).

\section{Shandon's journey to ACA status}

Cork is Ireland's second largest city. Shandon, an inner-city district located on the lower level of Cork's distinctive northern ridge, is one of the city's most historically, socially and architecturally important areas. Shandon has a long and varied social and economic history stretching more than 800 years. It was once a major trading zone through which significant volumes of agricultural produce were exported throughout the British Empire (Foynes 2007). Impressive keynote buildings, coupled with a medieval street pattern and dense residential terraces, define Shandon's urban form. The street pattern, which has remained largely unaltered since the 1600 s, is notable for its many narrow lanes and streets built at the human scale. Urban form is relatively dense, though not characterised by high-rises, as few buildings exceed three storeys. Shandon's built heritage comprises an eclectic mix of architecture, including Georgian, medieval and Victorian and other styles, including Dutch vernacular (McCarthy 2011).

The rich built and social heritage in Shandon distinguish the area as an important ensemble with substantial heritage value. Keynote buildings include St Anne's Church, The 
North Cathedral, Skiddy's Almshouse, the Butter Exchange Building and the Firkin Crane. Image 1 shows an aerial view of Shandon and its location adjacent to the River Lee. Clearly visible in this image are the steeple and bells of St Anne's Church, the distinctive circular structure of the Firkin Crane, two deconsecrated graveyards now used as public parks, and Skiddy's Almshouse, which sits between the two parks.

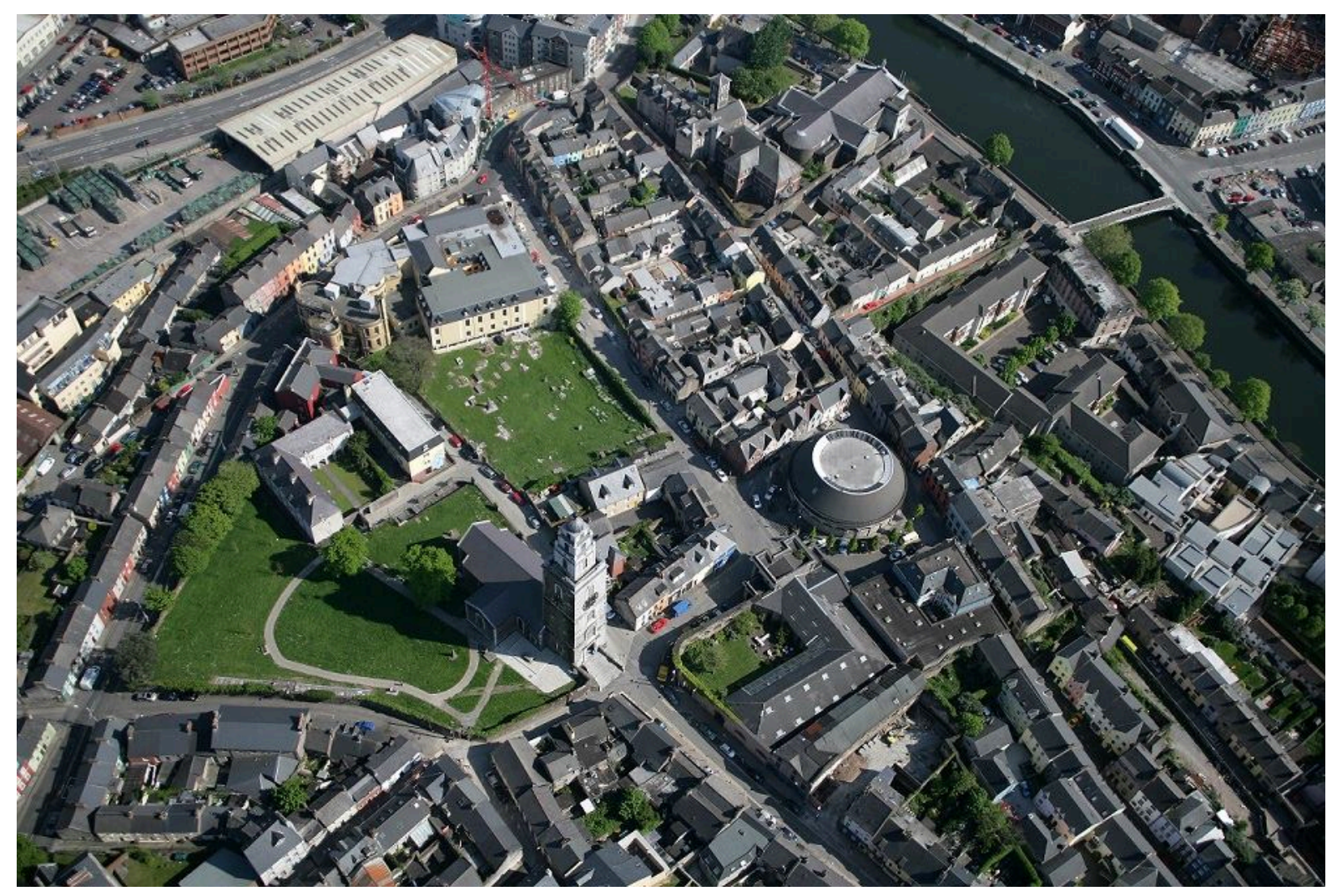

Image 1. Aerial view of the historic core of the Shandon ACA (source: $x x x x x$ )

Cork city entered a period of economic decline from the 1970s (O'Callaghan and Linehan 2007); Shandon was not spared. The area continued to lag even as the wider city started to recover in the 1990s. The lack of a coherent planning framework was partly responsible for Shandon's stagnation. Calls for sensitive development and careful conservation of the area's built heritage consequently went unheeded for many years. The local community attempted to respond on occasion, but their efforts were often uncoordinated, limited or focused only on single issues. This action nonetheless produced 
occasional positive outcomes, not least the adaptive re-use of a number of industrial buildings in the 1980s. During that time the former Butter Exchange Building was converted into a craft centre and museum and the Firkin Crane was converted into a dance, live music and theatre venue ( $\mathrm{CCC}$ no date). These conversions involved reimaging old industrial buildings as economically productive contemporary spaces through a process Cho and Shin $(2014,69)$ describe as 'the cultural valorization of obsolete spaces as heritage spaces'. This involves institutionally generating and legitimizing new cultural meanings to create new cultural objects from existing places.

In 2007, local residents, traders and artists formed the Shandon Area Renewal Association, who actively linked with other groups to provide coordinated community input into efforts to reinvigorate the area. These ongoing community-led initiatives seek to exploit Shandon's tourism, economic and cultural potential, while conserving its built heritage and distinct architectural character. A key early outcome was Cork City Council's designation of the ensemble as an ACA under the Cork City Development Plan 2009-2015 (CCC 2009a). The subsequent Cork City Development Plan 2015-2021 maintains conservation protections for the Shandon ACA (CCC 2014). Image 2 shows the defined boundaries of the Shandon ACA. The Shandon ACA is flanked by the Blackpool ACA to the north, the Coburg Street and St Patrick's Hill ACA to the west and the North Main Street ACA on the southern banks of the River Lee. 


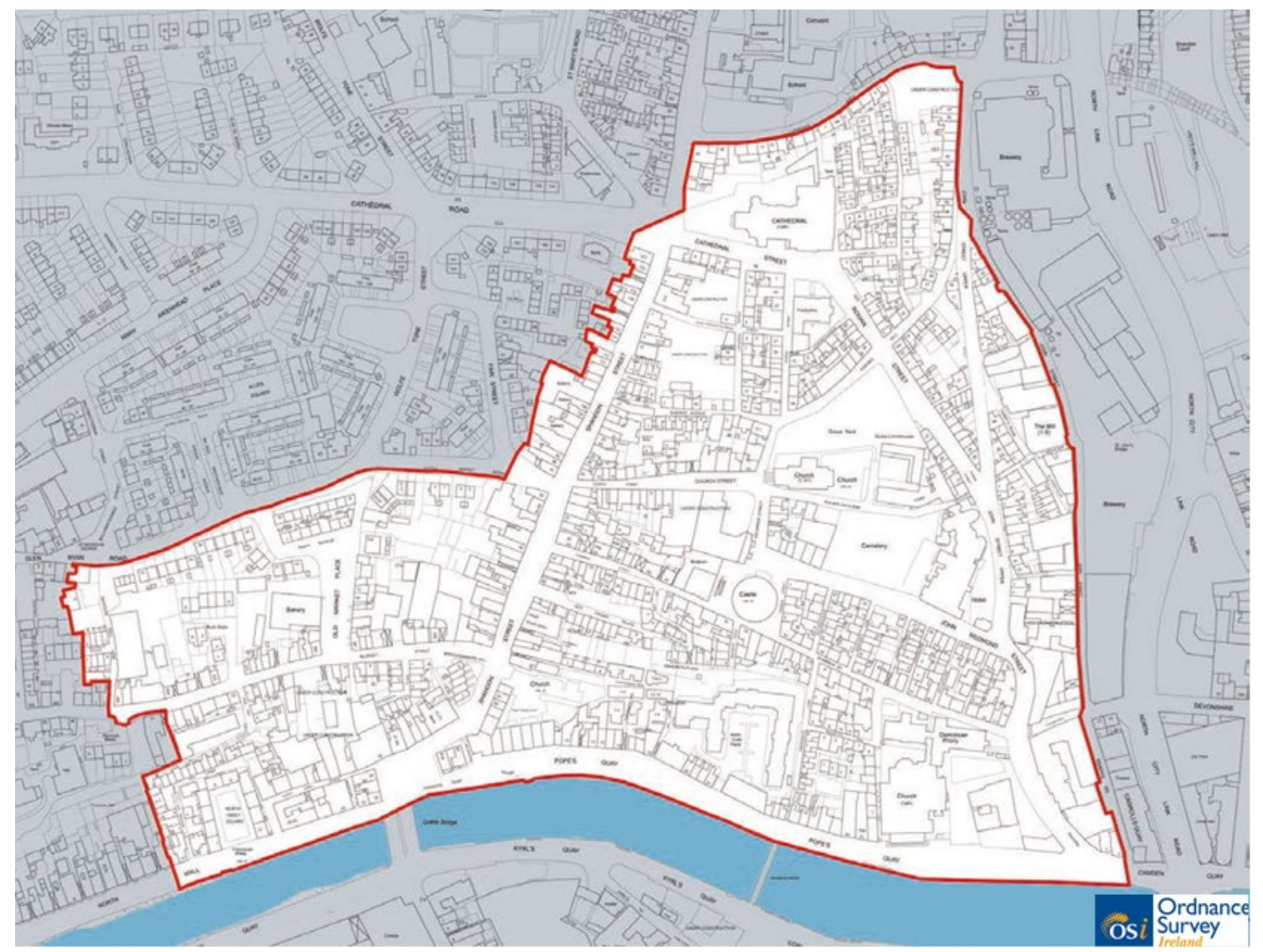

Image 2. Shandon ACA Boundary Map (Source: Cork City Council \& Ordinance Survey Ireland; reproduced with permission.)

Cork City Council states that an ACA designation is intended 'to preserve and enhance the character and appearance of [an] area' (CCC 2009b, 2). Shandon's designation as an ACA was important for two reasons. First, it provided formal acknowledgement by Council of the broad heritage value and distinctive character of the Shandon ensemble, both independently and also within the wider context of Cork city. Second, it provided a set of statutory policy and regulatory mechanisms to allow Cork City Council to ensure the ongoing protection of Shandon's built heritage through the enforcement of strict development management standards. For example, development consent is required before works can be carried out to the exterior of any structure in Shandon, with works that may be categorised as exempted development elsewhere being subject to formal planning appraisal in Shandon. 
Further, Cork City Council may insist on adherence to specific design and material standards in relation to roofing, windows and doors, rendering, walls, curtilage and attendant grounds for both residential and commercial buildings (CCC 2009b; DAHG 2011, 5). Municipal works and works by utility companies are also subject to conservation requirements to ensure like-for-like replacement of disrupted or damaged features in the public realm.

\section{Reflecting on heritage conservation in the Shandon ACA}

Heritage conservation is an ongoing process because built environments are never complete (Harvey 2001). Built environments change and grow over time in response to the interplay between people and space. The remainder of this paper examines the interrelated and overlapping physical, spatial, social and political dimensions of heritage conservation in Shandon. The subjectivity and value-politics of planning processes designed to identify and define built heritage as worthy of conservation are discussed throughout.

\section{Achieving Complementarity in the Shandon ACA}

The physical dimension of ensemble conservation relates to the preservation of existing built heritage and the sensitive management of new development (Orbasli 2000). This is to ensure that past, present and future urban forms combine to form recognisable spaces that are understood as continuous and complimentary by people using the space. The emphasis of the physical dimension is on physical appearance and relates to the conservation of the urban fabric or townscape including old and new buildings, groups of buildings and other features like street furniture and plantings (Orbasli 2000).

Cork City Council's role in overseeing the conservation of the physical elements of Shandon's built heritage is articulated through the Cork City Development Plan 2015-2021. Cork City Council identify a number of benefits associated with protecting and enhancing the 
physical character of ACAs (CCC 2009b). Benefits include improved property values, stringent preservation of the public realm and residents gaining a better sense of connection to the area. This is because preserving built heritage and retaining original features can make an area more desirable to current and potential residents, as well as visitors. Strategies enacted through ACA designation include prohibiting works that remove or damage attractive street features including historic road paving, railings, street furniture and kerb stones. Whilst conservation of built heritage can protect buildings and spaces, it can also lead to confusion, contention or resentment between property owners and planners when conservation strategies are perceived to unreasonably impede development (Bourke 2010).

The Cork City Development Plan 2015-2021 (CCC 2014) provides conservation objectives relative to specific aspects of Shandon. These are divided into three categories: protected structures; protected monuments and places; and protected views and prospects. Twenty four individual buildings in Shandon are identified as protected structures under the Plan. This means that any external or internal works or material changes of use are subject to greater levels of scrutiny by city planners and conservation officials, including An Taisce. Shandon is home to seven protected monuments and places, ranging in size and scale from old graveyards to the edifice and grounds of St Anne's Church. Any proposed works pertaining to, or impacting on, these protected monuments and places are subject to more intense planning scrutiny to avoid damage to their heritage value. The specific importance of St Anne's Church to Cork's skyline is demonstrated by protection of nine distinct linear views of the building from various parts of Cork City. A view over and across the entire Shandon townscape from Bell's Field, an adjacent, elevated green-space, is also protected. These conservation strategies and statutory protections safeguard Shandon's heritage provide a strong regulatory basis to ensure that people using the space can appreciate the physical fabric of Shandon as continuous and complimentary. 


\section{Achieving Compatibility in the Shandon ACA}

The spatial dimension of urban conservation understands built environments as holistic, interrelated and compatible (Orbasli 2000). It views the city as a whole, incorporating many spaces and uses, as well as the movement of people and traffic. There is a close link between spatial form and economic planning in many heritage ensembles, which provides a basis for various stakeholders to interact with planners. Stakeholders may include other municipal departments, city managers, residents, property developers and tourism promoters. Each of these may place specific demands on a heritage ensemble to improve economic potential, such as improved access, more car parking and changes to the function or form of specific spaces (Orbasli 2000, 19). The pursuit of compatibility often requires local planning authorities to mediate economic demands without injuriously compromising the character or spatial arrangement of an ensemble.

Heritage ensembles are regularly marketed to tourists to leverage economic return (Al-hagla 2010; Pendlebury, Short and While 2009). Irish heritage tourism industry expanded substantially in recent decades (Johnson 1999). Indeed, national guidance for heritage protection in Ireland advocates the use of heritage ensembles as sites for tourism experiences (DAHG 2011, 14). Shandon is increasingly used as the backdrop for public art spectacles, parades and community festivals, which are a significant contributor to the local economy. The scope, frequency and ambition of these events increased markedly from the mid-2000s. Most are specifically designed to take advantage of the area's unique built heritage, spatial form and proximity to the city centre. The local built heritage and spatial form of Shandon is arguably a central part of these festivals, functioning simultaneously as a drawcard for attracting visitors and as a unique stage around which the festivals are created. For example, heritage buildings were used to great effect as the canvas for a series of reverse graffiti 
murals depicting the past and present citizens of the local area as part of the Big Wash Up in 2009 (Grant-Smith and Matthews 2015). Similarly, the Voices of Shandon Festival in 2013 saw flags created by residents festooned between and around landmark buildings, most notably the spire of St. Anne's Church. Finally, the annual Dragon of Shandon Halloween Parade is planned around the local streetscape to evocative effect every Halloween when a thirty-six foot dragon, accompanied by an assortment of creatures from the underworld, emerges from Butter Exchange building and weaves its way through Shandon's narrow streets.

Achieving spatial compatibility in Shandon can be challenging because much of the current economic basis of the area relies on tourism. Certainly Shandon's architectural heritage forms part of Cork's tourist appeal but its importance is not without costs to the local area. Leveraging economic return by marketing heritage ensembles to tourists can be both advantageous and disadvantageous (Al-hagla 2010; Bayliss 2004; Herbert 1995; McManus 1997). There is a complex relationship between cultural heritage and tourism in which culture can evolve from being a shared entity amongst communities to a commodity that can be exploited for the benefit of tourists (Herbert 1995; Newby 1994). Conserving and marketing built heritage may erode the very qualities that combine to create forms of heritage worth conserving. While there is no firm evidence to suggest that this is case in Shandon, there are emerging conflicts between residents and tourism activities. An example is the issue of parking, which is already constrained as a result of Shandon's close-knit urban form. Nepravishta (2015) notes that parking pressures can create conflicts between residents and tourists in urban heritage areas. Conflicts can impact the attractiveness of an ensemble to both groups. Planners can try to safeguard spatial compatibility in heritage ensembles by ensuring that economic opportunities are not permitted to reduce the desirability of the area as a place where people want to live. The pursuit of these goals requires ongoing consultation with 
residents and local businesses particularly with respect to contentious issues such as parking, congestion and late night trading.

\section{Achieving Continuity in the Shandon ACA}

The social dimension of urban conservation concerns 'the user, the local community and the urban population' (Orbasli 2000, 19). It understands that continuity in heritage ensembles is realised through the ongoing lived experiences of residents and people who frequently engage with the space. Continuity through heritage conservation can help people to gain awareness of 'continuity that exists in human creation, glimpse a past that they receive with admiration and gratitude, and project the future to which they will transmit the results of their own endeavours' (Edson 2004, 345). Continuity of conservation is contingent on the continuation of active urban life within the conservation area. The nexus between past and present social experiences and a conservation area create a sense of social identity and belonging. As distinct from the physical and spatial dimensions of conservation, the principal actors in the social dimension are the residents who use the space daily. Planners, municipal departments, elected representatives, property developers, tourism promoters and other stakeholders can only effectively communicate with residents if lines of communication are specifically established. Communication generally needs to be invited by residents and is contingent on their participation.

Tweed and Sutherland (2007) consider processes associated with identifying and conserving built heritage. They discuss a process referred to as 'heritage by appropriation', which usually emerges from focused exploration of how built heritage acquires status through its use by the public. The Shandon ACA identification and designation process was heavily informed by a program of community consultation throughout 2008. The Shandon Area Renewal Association (SARA), an umbrella group comprised of residents, businesses and 
community actors in Shandon, was instrumental in initiating communication with planners and conservation staff from Cork City Council. SARA actively facilitated ongoing dialogue between council, planners and local residents. Representatives from SARA's internal planning committee met regularly with members of Cork City Council's planning department and the City Conservation Officer. Proposals, discussions and issues of note were then discussed amongst the wider SARA group at monthly meetings.

The extensive communication between planners and SARA meant that Shandon's designation was openly discussed by the people who most frequently used the space. Local identity and interest amongst residents towards enhancing Shandon's heritage remains strong, as evidenced by community-led efforts towards conservation and beautification projects. Such projects rely on volunteer labour and materials budgets often come through community improvement grant schemes administered by Cork City Council and the Department of Environment. Recurring initiatives include house-painting schemes, landscaping projects, graffiti removal and frequent volunteer-led area clean-ups. Recent high-profile communityled projects include the restoration of community gardens and allotments, known locally as the Green Gardens, and significant efforts to engage with government agencies to once more repurpose the Butter Exchange Building, following its closure as a craft centre in 2009.

\section{Achieving Connection in the Shandon ACA}

A political dimension of heritage conservation often intersects the physical, spatial and social dimensions (Harvey 2001, Orbasli 2000). The physical dimension derives from the subjectivity of decisions relating to heritage designation, which are actively shaped by the values of participant actors. The identification of heritage is neither neutral nor objective (Harvey 2001; Negussie 2004). Politicised and contested value-judgements shape decisions on what, how, when and whether to conserve (McManus 2000; Parkinson, Scott and 
Redmond 2015). McCarthy (2012) asserts that decisions to protect a physical embodiment of heritage are a reflection of contemporary values and cannot be considered apart from the political structures within which they are made. As Baish (2014) summarises, conservation practices occur at the intersection of townscape and mindscape. Decisions around ACA designation are thus "filtered with reference to the present, whenever that "present" actually is' (Harvey 2001, 327). As such, heritage conservation processes become politicised as they seek to connect the past, present and future of an ensemble by subjectively distilling historical values through contemporary perceptions.

Heritage designations can become processes of commodification where politicised interpretations of an ensemble's heritage become focused on particular tangible or intangible values (Ahmed 2006; Vakhitova 2015). Values may be time-dependent, linked to specific ideologies and potentially unconnected to local experience. Further, preserving the past may act to reinforce privilege as 'artefacts and spaces... are imbued with qualities and values, which need to be defined and redefined, by each generation' (van Oers 2010, 13-14). This suggests that decisions may not always concur with the views of some who frequently interact with an ensemble. This may occur even if decisions are made in a context of open communication and participation, as some views and participants are given greater legitimacy than others. This can create tension between stakeholders, particularly if some feel their choices and opportunities may be adversely conditioned by conservation designations that might constrain individual private property rights or use of space (Bourke 2010).

Similar concerns could be raised that distilling Shandon's historical value through politicised contemporary perceptions could lead to negative future impacts in which heritage branding and marketing of the area occurs at the expense of those who live and work there. This could happen through a process of selectively depicting and preserving Shandon's heritage in a way designed to maximise its appeal for visitors and casual users. A potential 
outcome could result in Shandon's urban form and appearance being rigidly protected in order to create an unchanging ensemble. There is a need to consider how formalised heritage conservation processes, such as ACA designation, might have the perversely foreclose opportunities for change; inappropriately managed ACAs may have the potential to calcify the urban form and to make it static. It must be remembered that cities are living things and not archaeological sites (Orbasli 2015).

Politicised decisions around ACA designation and associated threats could affect Shandon. Ensuring that the area benefits fully from its ACA status, while minimising any negative impacts, requires ongoing communication between planners, residents and other stakeholder groups who connect with and to the area. Mediating the politics of these processes and the competing social, spatial and economic factors is an ongoing challenge. So too is facilitating the continuation of the strong community capital built up by groups like the Shandon Area Renewal Association. Orbasli (2000, 2015) suggests that the value of urban heritage is not simply in the historic built fabric and spatial aspects of a townscape, but also in the life of its contemporary residents' community. Remaining mindful of this interplay and not sacrificing it for short-term political ideology or gain is important for the Shandon ACA as it continues to seek authentic connections between its past, present and future.

\section{Conclusion}

Formalised planning-led conservation approaches, like Architectural Conservation Areas, provide the opportunity to show 'respect for the inherited townscape' (van Oers 2010, 12) and to ensure that historic features can work in tandem with contemporary needs. Planningled conservation efforts targeting the broader ensemble have important cultural, physical, social, spatial and economic bases but are far from an apolitical endeavour. The designation of Architectural Conservation Areas are reflective of this as the process provides a formal 
mechanism through which to identify what is considered worthy of conservation. This is directly influenced by the values of participant actors and the ways they wish project those values to others, both now and over time. Shandon's ACA designation and enforcement processes to date suggest that managing and mediating competing objectives is achievable at the ensemble scale but that careful attention is needed to maintain the relevance, workability and continued community support of planning-led heritage conservation.

On this point, despite being subject to the same statutory protections as Shandon, the neighbouring ACA of Blackpool has been identified as 'a real cause for concern' due to its high number of derelict buildings and ill-kempt facades (Sheridan 2013). By contrast Shandon appears to have more successfully integrated heritage priorities connected to its designation as an ACA into processes of community renewal and of heritage protection. An important differentiating characteristic between the two ACAs is the active involvement of community members, local business and residents in the stewardship of heritage assets. The difference in outcomes for the two areas underscore the importance of local participation, ownership of space and the politics of local identify in realising the objectives of Architectural Conservation Areas.

\section{References}

Ahmad, Y. 2006. The scope and definitions of heritage: From tangible to intangible. International Journal of Heritage Studies 12 (3): 292-300. doi:10.1080/13527250600604639

Al-hagla, K. S. 2010. Sustainable urban development in historical areas using the tourist trail approach: A case study of the cultural heritage and urban development (CHUD) project in Saida, Lebanon. Cities 27 (4): 234-248. doi:10.1016/j.cities.2010.02.001 
Ashworth, G. J. 2002. Conservation designation and the revaluation of property: the risk of heritage innovation. International Journal of Heritage Studies 8 (1): 9-23.

Baish, L. A. 2014. Heritage as Part of Scape: Townscape, Landscape, Mindscape. Unpublished Dissertation, Master of Resource and Environmental Planning, Massey University, New Zealand. http://mro.massey.ac.nz/handle/10179/6889

Bannon, M., and B. Bradley. 2007. Planning Modern Ireland. Dublin: University College Dublin.

Bayliss, D. 2004. Creative planning in Ireland: the role of culture-led development in Irish planning. European Planning Studies 12 (4): 497-515. doi:10.1080/0965431042000212759

Bianca, S. 2010. Historic cities in the 21st century: core values for a globalizing world. In R. van Oers and S. Haraguchi (Eds) Managing Historic Cities, Paris: World Heritage Centre, UNESCO, pp. 27-34.

Bourke, A. G. 2010. Becoming European? Constructing Identity in Urban Regeneration Discourse in Ireland. Formations: The Graduate Center Journal of Social Research, 1 (1): 81-102. http://dev.ojs.gc.cuny.edu/index.php/formations/article/view/675

Cho, M., and S. Shin. 2014. Conservation or economization? Industrial heritage conservation in Incheon, Korea. Habitat International 41: 69-76. doi:10.1016/j.habitatint.2013.06.011

Cork City Council (CCC). 2009a. Cork City Development Plan 2009-2015 Volume 3 Specific Built Heritage Objectives. Cork: Cork City Council.

Cork City Council (CCC). 2009b. Architectural Conservation Areas (ACAs): Advice and Guidance for Owners and Occupiers. Cork: Cork City Council. http://epublications.snap.com.au/ebook/ebook?id10036591\#/0 
Cork City Council (CCC). 2014. Cork City Development Plan 2015-2021: Volume 3 Specific Built Heritage Objectives. Cork: Cork City Council.

http://www.corkcitydevelopmentplan.ie/images/Downloads/Volume\%203\%20Heritage. pdf

Cork City Council (no date) Cork Past and Present. http://www.corkpastandpresent.ie/places/ Accessed 24 March 2016

Department of Arts, Heritage and the Gaeltacht (DAHG). 2011. Architectural Heritage Protection: Guidelines for Planning Authorities. Dublin: The Stationary Office. http://www.buildingsofireland.ie/FindOutMore/Architectural $\% 20$ Heritage $\% 20$ Protectio n\%20-\%20Guidelines\%20for\%20Planning\%20Authorities\%20\%282011\%29.pdf

Dublin City Council. 2016. Architectural Conservation Areas.

http://www.dublincity.ie/main-menu-services-planning-heritage-and-conservationconservation/architectural-conservation-areas Accessed 13 March 2016.

Edson, G. 2004. Heritage: Pride or passion, product or service? International Journal of Heritage Studies 10 (4): 333-348. doi:10.1080/1352725042000257366

Foynes, P. 2007. Walking Shandon: A guide to the historic heart of Cork. Cork: Cork Butter Museum Publications.

Grant-Smith, D. and T. Matthews. 2015. Cork as canvas: Exploring intersections of citizenship and collective memory in the Shandon Big Wash Up murals. Community Development Journal 50 (1): 138-152. doi:10.1093/cdj/bsu030

Handler, R. 1987. Heritage and hegemony: Recent works on historical preservation and interpretation. Anthropological Quarterly 60 (3): 137-141. http://www.jstor.org/stable/3317633

Harrison, R. 2013. Heritage: Critical approaches. Abingdon: Routledge. 
Harvey, D. C. 2001. Heritage pasts and heritage presents: Temporality, meaning and the scope of heritage studies. Internal Journal of Heritage Studies 7 (4): 319-338. doi:10.1080/13581650120105534

Herbert, D. T. 1995. Heritage places, leisure and tourism. In Herbert, D. T. (Ed) Heritage, tourism and society, London: Mansell, pp. 1-20.

Hobson, E. 2001. Value and control: perceptions of conserving the built environment in local planning authority practice. Environment and Planning B: Planning and Design 28 (3): 461-474. doi:10.1068/b2739

Hubbard, P. 1993. The value of conservation: a critical review of behavioural research. Town Planning Review 64 (4): 359-369. doi:10.3828/tpr.64.4.v758731671422276

Johnson, N. C. 1996. Where geography and history meet: Heritage tourism and the big house in Ireland. Annals of the Association of American Geographers 86 (3): 551-566. doi:10.1111/j.1467-8306.1996.tb01766.x

Johnson, N. C. 1999. Framing the past: time, space and the politics of heritage tourism in Ireland. Political Geography 18 (2): 187-207. doi:10.1016/S0962-6298(98)00072-9 Maginn, D. 2014. Conservation and conflict in the $20^{\text {th }}$ Century built environment. Student Pleanail 2 (winter): 72-90.

McCarthy, C. 2012. Re-thinking threats to architectural heritage. International Journal of Heritage Studies 18 (6): 624-636. doi:10.1080/13527258.2011.608373

McCarthy, J. P. 2011. Dutch influence in the urban landscape of Cork City pre-1800: Fact or myth? Dutch Crossing 35 (1): 63-88. doi:10.1179/155909011X12930363744188

McManus, P. 2000. Conservation. In Johnston, R. J., Gregory, D., Pratt, G. and Watts, M. (Eds) Dictionary of Human Geography, Oxford: Blackwell Publishers, pp.106-107. McManus, R. 1997. Heritage and tourism in Ireland: an unholy alliance? Irish Geography 30 (2): 90-98. doi:10.1080/00750779709478636 
Nasser N. 2003. Planning for urban heritage places: Reconciling conservation, tourism and sustainable development. Journal of Planning Literature 17 (4): 467-479. doi: $10.1177 / 0885412203017004001$

Negussie, E. 2004. What is worth conserving in the urban environment? Temporal shifts in cultural attitudes towards the built heritage in Ireland. Irish Geography 37 (2): 202-222. doi:10.1080/00750770409555843

Nepravishta, F. 2015. Conservation and rehabilitation of urban heritage and tourism: Skhodra case study. Online International Interdisciplinary Journal 5 (3): 26-36.

Newby, P. T. 1994. Tourism: Support or threat to heritage? In Ashworth, G. and Larkham, P. (Eds) Building a new heritage: tourism, culture and identity in the New Europe, London: Routledge, pp. 206-228.

O'Callaghan, C., and D. Linehan. 2007. Identity, politics and conflict in dockland development in Cork, Ireland: European Capital of Culture 2005. Cities 24 (4), 311 323. doi:10.1016/j.cities.2007.01.006

Orbasli, A. 2000. Tourists in Historic Towns: Urban Conservation and Heritage Management. London: E \& FN Spon Press.

Orbasli, A. 2008. Architectural Conservation. Oxford: Blackwell Publishing. Orbasli, A. 2015. World Heritge status can be a poisoned chalice for cities. The Conversation. 19 Feburary 2015, https://theconversation.com/world-heritage-statuscan-be-a-poisoned-chalice-for-cities-37784. Accessed 4 May 2015.

Parkinson, A., M. Scott, and D. Redmond. 2015. Competing discourses of built heritage: lay values in Irish conservation planning. International Journal of Heritage Studies, online ahead of print, 1-13. doi:10.1080/13527258.2015.1121404 
Parkinson, A., M. Scott, and D. Redmond. 2016. Revalorizing colonial era architecture and townscape legacies: memory, identity and place-making in Irish towns. Journal of Urban Design, online ahead of print 1-18. doi:10.1080/13574809.2015.1106917

Pendlebury, J. 2013. Conservation values, the authorised heritage discourse and the conservation-planning assemblage. International Journal of Heritage Studies 19 (7): 709-727. doi:10.1080/13527258.2012.700282

Pendlebury, J., M. Short, and A. While. 2009. Urban world heritage sites and the problem of authenticity. Cities 26 (6): 349-358. doi:10.1016/j.cities.2009.09.003

Pickard, R. 2002. A comparative review of policy for the protection of the architectural heritage of Europe. International Journal of Heritage Studies 8 (4): 349-363. doi:10.1080/1352725022000037191

Ryberg-Webster, S., and Kinahan, K. L. 2014. Historic preservation and urban revitalization in the Twenty-first Century. Journal of Planning Literature 29 (2): 119-134. doi:10.1177/0885412213510524

Sheridan. C. 2013. Local historian says protecting Cork's historical heritage is a must. Irish Examiner 16 August 2013. http://www.irishexaminer.com/lifestyle/artsfilmtv/localhistorian-says-protecting-corks-historical-heritage-is-a-must-239967.html

Shipley, R. 2000. Heritage design and property values: is there an effect? International Journal of Heritage Studies 6 (1): 83-100.

Skea, R. 1996. The strengths and weaknesses of conservation ensembles. Journal of Urban Design 1 (2): 215-228. doi:10.1080/13574809608724382

Taylor, J. 2013. Intergenerational justice: a useful perspective for heritage conservation. CeROArt: Conservation, Exposition, Restauration d'Objects d'Art, accessed 30 October 2013, http://ceroart.revues.org/3510 
Townshend, T., and J. Pendlebury. 1999. Public participation in the conservation of historic areas: Case-studies from north-east England. Journal of Urban Design 4 (3): 313-331. doi:10.1080/13574809908724453

Tweed, C., and M. Sutherland. 2007. Built cultural heritage and sustainable urban development. Landscape and Urban Planning 83 (1): 62-69. doi:10.1016/j.landurbplan.2007.05.008

UNESCO. 2011. A new international instrument: The proposed UNESCO recommendation on the historic urban landscape (HUL). Paris: UNESCO.

Vakhitova, T. V. 2015. Rethinking conservation: managing cultural heritage as an inhabited cultural landscape. Built Environment Project and Asset Management 5 (2): 217-228. doi:10.1108/BEPAM-12-2013-0069

van Oers, R. 2010. Managing cities and the historic urban landscape initiative - an introduction. In van Oers, R. and Haraguchi, S. (Eds) Managing Historic Cities, Paris: World Heritage Centre, UNESCO, pp. 7-18.

Veldpaus, L., Pereira Roders, A. R. and Colenbrander, B. J. F. 2013. Urban heritage: putting the past into the future. The Historic Environment 4 (1): 3-18. doi:10.1179/1756750513Z.00000000022

Whitehand, J. W. R., and K. Gu. 2010. Conserving urban landscape heritage: A geographical approach. Procedia Social and Behavioral Sciences 2 (5): 6948-6953.

doi:10.1016/j.sbspro.2010.05.047 